\title{
Improving the Socio-Economic Wellbeing of Rural People: Analysis of the Impact of the Community and Social Development Project (CSDP) tn Odukpani Local Government Area of Cross River State, Nigeria
}

\author{
Magareth A. Ndem ${ }^{1}$, Pius U. Angioha ${ }^{2, *}$, Emmanuella Dike ${ }^{3}$ \\ ${ }^{1,2,3}$ Graduate student, University of Calabar \\ Cross River State, Nigeria \\ "Corresponding author's email: angiohapius [AT] unical.edu.ng
}

\begin{abstract}
The objective of the study is to examine the impact of Cross River Community and Social Development Project (CSDP) on the socio-economic wellbeing of the rural poor of Odukpani Local Government Area of Cross River State, Nigeria.the study specifically examine the extent to which the Cross River Community and Social Development Project (CSDP)in terms of the provision of socio-economic facilities and provision of basic health care facilities relates to the socio-economic wellbeing of the rural poor of Odukpani Local Government Area of Cross River State, Nigeria. the study adopted The Expost Facto research method. The sample size for the study is three hundred and eighty four (384) derive from 13 wards in Odukpani Local Government Area drawn using the purposive sampling technique, the simple random technique, and the systematic technique. The instrument of data collection was the questionnaire. Data collected from the field was analysed hypothesis by hypothesis, each was testing using Pearson Product Moment Correlation statistical tool at 0.05 level of significance. Result from the analysis of data revealed that Cross River Community and Social Development Project (CSDP)in terms of the provision of socio-economic facilities and the provision of basic health care facilities significant relates to the socio-economic wellbeing of the rural poor of Odukpani Local Government Area of Cross River State, Nigeria. The study therefore recommends that Socio economic activities/programmes such as skill acquisition should be extended to other local government areas of the state as this will avail other community to benefit positively from same.
\end{abstract}

Keywords--- Cross River Community and Social Development Project (CSDP), socio-economic wellbeing, socio economic facilities, health care facilities

\section{INTRODUCTION}

Over the years, the undeveloped nature of rural communities and its transformation had been of major concerns to successive Nigerian governments at all levels. Efforts aimed at modernizing the rural areas or at least improve the socioeconomic wellbeing of the rural population by the federal, state and local government have not yielded any appreciable results. Government had at various times introduced policies and programmes aimed at opening up rural areas, providing educational facilities, provisions of agricultural inputs and literacy programmes, health facilities etc. (Ihejiamaizu, 2002; Ojong, Iji \& Angioha, 2019; Attah \& Angioha, 2019). However, most of these policies and programmes have had minimal or no significant effect in changing the lives of the rural people. In cases where some levels of successes are recorded, the programmes and policies are not sustainable. Consequently, our rural areas remain underdeveloped without the basic amenities, which guarantee good standard of living. Thus, the gap between the rich urban centres and the rural poor has continued to widen (Angioha, Nwagboso, Ironbar \& Ishie, 2018). Accordingly, Ering (2005), Ering, Nwagbara and Ushie (2006) argued that the nation`s rural development policies and programmes often lack the people participation which to a large extent affect the ownership and sustainability.

In Cross River State, It has been observed that several policies, programmes and projects have been initiated and implemented in rural communities. These policies/programmes were executed in the area of social welfare services, education, agriculture, health care, electrification, potable water supply and others. However, in spite of these policies, projects and programmes, rural poverty had persisted and the socio-economic wellbeing of the rural communities have not improved significantly over the years. Most of the rural populations in the state are still unable to meet their basic needs and have remained underdeveloped. This above scenario captures the socio-economic situation in Cross River rural 
communities, particularly in Odukpani Local Government Area (LGA) where most of the rural infrastructures like pipe borne water, rural electrification, roads, schools, and health facilities are both in short supply and poor state of disrepairs. These problems have made it difficult for rural dwellers to experience improved socio-economic wellbeing in the study area.

To correct this anomaly and modernize the rural communities of Odukpani LGA, the Cross River Community and Social Development Project (CSDP) was created as intervention agency to help increase access of rural communities to micro-projects. It was against this backdrop that the study was conducted to access the impact of CSDP on the socioeconomic wellbeing of the rural poor of Odukpani Local Government Area of Cross River State, Nigeria.

\subsection{Objective of the study}

The objective of the study is to examine the impact of Cross River Community and Social Development Project (CSDP) on the socio-economic wellbeing of the rural poor of Odukpani Local Government Area of Cross River State, Nigeria.the study specifically;

i. Examine the extent to which the Cross River Community and Social Development Project (CSDP)in terms of the provision of socio-economic facilities relates to the socio-economic wellbeing of the rural poor of Odukpani Local Government Area of Cross River State, Nigeria.

ii. Examine the extent to which the Cross River Community and Social Development Project (CSDP)in terms of the provision of basic health care facilities relates to the socio-economic wellbeing of the rural poor of Odukpani Local Government Area of Cross River State, Nigeria.

\subsection{Research Hypotheses}

i. The Cross River Community and Social Development Project (CSDP)in terms of the provision of socio-economic facilities does not significantly relates to the socio-economic wellbeing of the rural poor of Odukpani Local Government Area of Cross River State, Nigeria

ii. The Cross River Community and Social Development Project (CSDP)in terms of the provision of basic health care facilities does not significant relates to the socio-economic wellbeing of the rural poor of Odukpani Local Government Area of Cross River State, Nigeria.

\section{$1.1 \quad$ Literature Review}

\section{LITERATURE REVIEW AND THEORETICAL FRAMEWORK}

\subsubsection{An overview of the Cross River community and social development project (CSDP)}

Apart from the national efforts aimed at developing the country, the States had over the years, put up different policies and programme to foster development. One of such efforts is the establishment of the Community and Social Development Agency (CSDA) in 2009, to implement the Cross River State Community and Social Development Project (CR-CSDA, 2013), in collaboration with former President Obasanjo National Economic Empowerment Development Strategy.

The Cross River State Government, through the Cross River State community and social development agency has been able to implement some development projects in rural communities in the state. For instance, the initiation of the rural development programme in Cross River State is directed at rural transformation in four (4) Local Government Area of Cross River State including Odukpani Local Government Area. Over five roads linking many rural communities where constructed. Aside the creation of roads that links the rural community to urban area in the state, the state embarked upon rural electrification in 2000, in which many of the local government benefited including Odukpani Local Government (This day live, 2012).

Also, according to the Cross River State community and social development project impact evaluation report (2013), CSDP embarked on transformation projects in seven sectors which are - education, water, health, transport, rural electrification, socio-economic activities and environment and natural resources. These projects were undertaken all local government areas of the state including Odukpani. The effect of the CSDP intervention in community development in state rural areas is seen in the different sectors. In the education sector, the average school age enrolment increased by 1136 pupils, also the average time taken to travel to school reduced from 42 minutes to 24 minutes. Also, the number of schools increased (CR-CSDP, 2013). 
In the health sector, the CSDP embarked on the provision of twenty-three (23) health projects but nineteen (19) were finally implemented which includes the construction of health posts, furnishing, and drugs supply. The outcome of these projects in Cross River State Rural Communities as a result of the CSDP intervention include : people attending health centres for treatment or counselling, pregnant women attending anti/post-natal clinic, children immunized, and medical staffs deployed to rural communities, the average time taken to reach health clinic and average distance has reduced considerably. Thus, health services delivery have improved significantly through the interventions by the CSDP (CRCSDP, 2013).

In the overall socio-economic activities, the Community and Social Development Project (CSDP, 2013) reported that fourteen(14) projects were completed in ten (10) communities of the state, which included Creek Town in Odukpani Local Government Area. The CSDP has affected rural transformation in Cross River State with the participation of the rural people. Even community members that reside outside the community are now major stakeholders in the development process of their communities. The result of the CSDP project according to its reports (2013) have added value to the livelihoods of the intervened communities

\subsubsection{Government provision of socio-economic facilities and socio-economic wellbeing of the rural poor}

According to Toyobo, Muli, and Adetunji (2014), rural areas in the country has been neglected in the area of provision of socio-economic facilities as the government at all levels focus more on the urban areas skill acquisition (education and training in a particular trade) are regarded to be very essential in improving agriculture and non-farm productivity and help families to have a better standard of living (Eskola \& Gasperini, 2010). In the opinion of Eskola and Gasperini (2010), skill acquisition for rural dwellers especially the women will contribute greatly to socio-economic development of the people. This is because skill development helps in improving rural productivity, employability and income-earning opportunities, and this can help promote a sustainable rural development and livelihoods.

Supporting the above opinion, Egunyomi and Ekom (2010) argued that in addressing poverty and improving socio-economic status of people, occupational and vocational skills acquisition for economic self-dependence of individual and communities cannot be overlooked. In other words, socio-economic facilities (in terms of skill acquisition) cannot be over looks in the effort to create a sustainable rural socio-economic development. Again, Egunyomi and Ekom (2010) posited hat sustainable socio-economic development cannot just be achieved by the more provision of skill acquisition according to them, for skill acquisition impact the individual and the community, the vocational skills programmes should have bearing with the social, cultural and economic contexts of the individuals and the community.

\subsubsection{Government health programmes and socio-economic wellbeing of the rural poor}

According to Anam (2012), the health status of members of a community can be used as a yardstick for measuring the wealth of that community. This in order words is rephrasing the popular slogan that says "Health is wealth". Thus, good health of members of rural community guarantees greater human development. This is because it constitutes a major driver of speedy economic, social and political development in rural communities. Bushy (2008) refer health as a complete state physical, mental and social wellbeing of a person and not just the absence of disease or infirmity. The inaccessibility to health care facilities in rural areas in Nigeria according to Ajala, Sanni and Adeyinka, (2005) is a major contributor to the underdevelopment state of the rural communities in Nigeria. He further stressed that for there to be sustainable rural development in rural communities, there must be adequate provision for their health and not just provision but accessibility too. In line with this, and with the intention of crating rural development in mind, the state government implemented some health programmes and projects in Odukpani among which are:

(i) Provision of health facilities within 30-minutes from communities (kekerete.tripod.com);

(ii) Donation of motorcycles for heath service delivery (ODU-LEEDS 2);

(iii) Enlightenment campaigns and health education;

(iv) Distribution of nets to prevent mosquito bite (Roll Back Malaria); and

(v) The ongoing health facility under construction in Ikoneto.

The provision of health facility within 30-minute from communities have made it easier for the people of Odukpani to access health service easily. This has helped in combating preventable death and reducing self-medication, which is a common practice among rural people. These have contributed to improved healthcare services delivering to Odukpani people. (kekerete.tripo.com). There are thirty-three (33) health facilities in Odukpani, these are comprised of 
sixteen(16) Health Posts, nine(9) Health Centres and eight (8) Comprehensive Health Centres owned by the University of Calabar Teaching Hospital (UCTH). In addition, there are private clinics owned by individual and organisations (ODULEEDS 2, 2013 - 2016).

Also, more health personnel's were employed by the government to run the various Health Centres. In contributing to the development of the health status of the area (Odukpani), motor cycles were donated to the various Health Centres (ODU-LEEDS, 2013 - 2016). The distribution of the insecticide treated nets was with the support of multinationals oil companies and this was in line with national effort at combating malaria. These various health projects have made impact in Odukapani local government. Although there are still some health challenges that need to be given attention in the local government area (ODU-LEEDS, 2013 - 2016), but the health programmes executed so far have impacted positively on the lives of the rural people of Odukapani.

\subsection{Theoretical Framework}

The study adopted the integrated rural development model associated with Abasi-Ekong 1981 and Hallet 1996. The model assumes that for the socio-economic and cultural base of the rural societies to be broadened through integrated efforts of mobilizing and utilizing human and natural resources. This could be achievable through the provision of services, creation of motivational and purchasing power through better supply of income and employment opportunities, and by creating a clear associations between agriculture (which is the major occupation of rural people), and service sectors in the rural areas rather than mere improvement of living conditions in terms of housing, food supply, water supply, education, feeder roads etc. Thus, the elements of this model includes the following: income for rural communities, reduced poverty and unemployment in rural areas, equal distribution of wealth and income for rural people, the provision of basic essentials into the country's political practice.

The implication of the above model for this study is that government and development agencies should include the rural people in the planning, formulating, and implementing process of policies, programmes and projects for rural development. In essence, the responsibilities of the Cross River State development agency for the development of Odukpani Local Government Area are multidimensional involving the provision of socio-economic facilities, educational facilities, health facilities etc, for rural communities in Odukpani. To achieve desired results, the Odukpani rural dwellers must be involved in the development process, they should be sensitized to identify opportunities and act on them. The reality of this model is that the whole burden of the development of Odukpani Local Government Area is not entrusted on the Cross River government alone, rather it is a partnership, though initiated by the state government with the Odukpani people to help improve their community needs.

\section{MATERIALS AND METHODS}

The Expost Facto research method was adopted. The Expost Facto research refers to the research in which the individual carrying out the research do not have any control over the independent variables as a result of the condition for study already existed and had taken place already (Ndiyo, 2005). Thus, the independent variables in the study were not manipulated by the researcher as they had already taken place before the study was carried out. The sample size for the study is three hundred and eighty four (384) derive from 13 wards in Odukpani Local Government Area.To draw a sample that truly represent the population of study, three sampling techniques were adopted, there are: (a) the purposive sampling technique, (b) the simple random technique, and (c) the systematic technique. The purposive sampling technique was used to select the 13 wards in Odukpani Local Government Area. The simple random sampling technique was used in selecting the ninety-six (96) villages sampled out of the 249 total villages in Odukpani Local Government Area. The systematic sampling method was used to select the actual household and respondents that formed the sample size. The households and respondents were systematically sampled by enumerating households into even and odd numbers and four (4) odd numbered households were systematically picked from each village selected to form the sample. One adult respondent was chosen from each household selected, which brought the total number of sample respondents to 384 respondents. The instrument of data collection was the questionnaire. Data collected from the field was analysed hypothesis by hypothesis, each was testing using Pearson Product Moment Correlation statistical tool at 0.05 level of significance.

\section{RESULTS AND FINDINGS}

Table 2 shows the distribution of projects executed in Odukpani rural communities by CSDP and the impact created. The provision of socio-economic facilities (in terms of skill acquisition and market stalls) has led to such impact as improved socio-economic wellbeing of the rural people. The provision of educational infrastructures (in terms of 
renovation of classrooms and provision of science equipment) has impacted the rural people by increasing their literacy level and they also have a comfortable and convenient learning environment. Also the provision of health care facilities (in terms of renovation of health care centres and provision of better medical services) has improved the health status of the rural people, also the distance to a health care facility has been reduced, and in addition, children of the rural people do not get affected by killer diseases since they are being immunized early. Skills acquisition has also contributed to the development of Odukpani people, as the skills acquired serves as a means of employment for the people.

Table 2

Distribution of impact of project executed

\begin{tabular}{|c|c|c|c|}
\hline \multirow{2}{*}{$\begin{array}{l}\text { Variables } \\
\text { Provision of socio-economic } \\
\text { facilities }\end{array}$} & Project Executed & \multicolumn{2}{|c|}{ Impact Created } \\
\hline & $\begin{array}{l}\text { 1) Provision of markets. } \\
\text { 2) Provision of lock up stalls. }\end{array}$ & 1) & $\begin{array}{l}\text { The socio-economic well-being } \\
\text { has significantly improved. }\end{array}$ \\
\hline & $\begin{array}{l}\text { 3) Provision of skills acquisition } \\
\text { centres }\end{array}$ & 2) & $\begin{array}{l}\text { The income of the people } \\
\text { increase significantly }\end{array}$ \\
\hline $\begin{array}{l}\text { Provision of health care } \\
\text { facilities }\end{array}$ & $\begin{array}{l}\text { 1. Renovation of dilapidated } \\
\text { Health Care Centres. }\end{array}$ & 1) & $\begin{array}{l}\text { Improved health status of the } \\
\text { rural people }\end{array}$ \\
\hline & $\begin{array}{l}\text { 2. Provision of better medical } \\
\text { Services }\end{array}$ & 2) & $\begin{array}{l}\text { Distance to a health care facility } \\
\text { reduced }\end{array}$ \\
\hline & 3. Affordable medical services. & 3) & $\begin{array}{l}\text { Increased immunisation of } \\
\text { children in communities. }\end{array}$ \\
\hline
\end{tabular}

Source: Field Survey, 2019

\subsection{Test of Hypotheses \\ 4.1.1 Hypothesis one:}

The Cross River Community and Social Development Project (CSDP) in terms of the provision of socio-economic facilities does not significantly relates to the socio-economic wellbeing of the rural poor of Odukpani Local Government Area of Cross River State, Nigeria. The independent variable here is the Cross River Community and Social Development Project (CSDP) in terms of the provision of socio-economic facilities, while the dependent variable is socio-economic wellbeing. The data was subjected to Pearson product Moment Correlation Coefficient analysis and the result is presented in table 3

Table 3

Showing the result of the analysis

\begin{tabular}{lllll}
\hline Variables & $\sum \mathrm{x}$ & $\sum \mathrm{x}^{2}$ & $\sum \mathrm{xy}$ & $\mathrm{r}$-cal \\
& $\sum \mathrm{y}$ & $\sum \mathrm{y}^{2}$ & & \\
\hline Coding scores & 15 & 55 & \multirow{2}{*}{1448} & 0.94 \\
No of respondents & 370 & 40092 & & \\
\hline
\end{tabular}

Significant at 0.05, r.cal $=0.94$, r-critical $=0.113$

Table 3 reveals the calculated table value of 0.94 is greater than the table value of 0.113 , based on this the null hypothesis is rejected and the alternative hypothesis accepted. This means that The Cross River Community and Social Development Project (CSDP) in terms of the provision of socio-economic facilities does not significantly relates to the socio-economic wellbeing of the rural poor of Odukpani Local Government Area of Cross River State, Nigeria.

\subsubsection{Hypothesis two:}

The Cross River Community and Social Development Project (CSDP)in terms of the provision of basic health care facilities does not significant relates to the socio-economic wellbeing of the rural poor of Odukpani Local Government Area of Cross River State, Nigeria. The independent variable here is the Cross River Community and Social Development Project (CSDP) in terms of the provision of basic health care facilities while the dependent variable is socio-economic wellbeing. The data was subjected to Pearson product Moment Correlation Coefficient analysis and the result is presented in table 4 
Table 4

Showing the result of the analysis

\begin{tabular}{lcccc}
\hline Variables & $\sum \mathrm{x}$ & $\sum \mathrm{x}^{2}$ & & \\
& & & & \\
& $\sum \mathrm{y} y$ & $\sum \mathrm{y}^{2}$ & & r-cal \\
\hline Coding scores & 15 & 55 & & \\
No of respondents & & & 1425 & 0.97 \\
\hline
\end{tabular}

Significant at 0.05 , r.cal $=0.97$, r-critical $=0.113$

Source: Field Survey, 2019

The table 4 reveals that the calculated table $r$ - value of 0.97 , which is greater than the critical value of 0.113 at 0.05 level of significance. With this result, the null hypothesis was rejected which implies that The Cross River Community and Social Development Project (CSDP)in terms of the provision of basic health care facilities significant relates to the socio-economic wellbeing of the rural poor of Odukpani Local Government Area of Cross River State, Nigeria.

\section{CONCLUSION AND RECOMMENDATION}

The Community and Social Development Projects are important stimulants of improved socio-economic wellbeing of the rural people. The findings of the study specifically established this in collaboration with the assertion of scholars in related studies. All the hypotheses showed there is a relationship or correlation between the dependent and independent variables which revealed that the provision of socio-economic facilities, provision of health care facilities all have positive implication on the socio-economic well-being of the rural people. The provision of these facilities has impacted upon the income, health status and even literacy level of the rural people. Recommendations

The study hereby recommends that;

(i) Socio economic activities/programmes such as skill acquisition should be extended to other local government areas of the state as this will avail other community to benefit positively from same.

(ii) To help boost further the health status of the people of Odukpani in particular and other local government communities in Nigeria, provision of health facilities/infrastructures should be optimized by government and nongovernment organisation.

\section{REFERENCES}

- Ajala, O., Sanni, L. \& Adeyinka, S. (2005). Accessibility to health care facilities: A panacea of sustainable rural development in Osun State, South-western Nigeria. Journal of Human Ecology, 18(2), 121-128.

- Anam, B. E. (2010). Rural development policies and their impact on the socio-economic lives of rural dwellers: An examination of Cross River State Rural Development Agency, Calabar. Unpublished M.Sc. Project Submitted to Graduate School, University of Calabar Nigeria.

- Anam, B. E. (2012). New perspectives on personnel management and organisation performance. Calabar: Kings View Publishing House.

- $\quad$ Angioha, P. U., Nwagboso, S. N., Ironbar, A. E. \& Ishie, E. U. (2018). Underemployment: A Sociological and Policy Analysis of Workers Well-Being in Hospitality Industry in Calabar, Cross River State, Nigeria. IOSR Journal of Humanities and Social Science (IOSR-JHSS), Volume 23, Issue 6, Ver. 5 (June. 2018) PP 57-66.

- Attah, F. M. \& Angioha, P. U. (2019). Development Agencies And Community Development: Assessment of the World Bank's Commercial Agriculture Development Project (CADP) in Calabar, Cross River State, Nigeria. International Journal of Research and Innovation in Social Science (IJRISS),

- Bushy, S. W. (2008). Evolving challenges in rural transformation. London: Macmillan.

- CSDP (2013). Clinical costs of colorectal cancer screening in 5 federally funded demonstration programs. Cancer, 119(Suppl. S15), 2863-2869.

- Egunyomi, D. A. \& Okora O. E. (2010). Comparative analysis of influence of some socio-economic variables on vocational skills acquisition programmes for adult learners in South-south, Nigeria. J Economics, 1(1), 33-43.

- $\quad$ Ering, S. O. (2005). The trickle down theory: An Appraisal of its Adequacy and policy effectiveness for economic development in Developing Countries in Nigerian, Journal of Social and Development Issues, 5(91), 151-161. 
- Ering, S. O., Nwagbara, E. N. \& Ushie, E. M. (2006). Sustainable rural development in Nigeria: Issues of methodology and policy, Journal of Development and policy, 1, 80-109.

- Eskola, T. \& Gasperine, L. (2010). Investing in Skills for Socio-economic Empowerment of Rural Women. Gender and Rural Employment Policy Brief \#2. (Retrieved on 28 February 2011)

- Ihejiamaizu, E. (2002). Sociology of Nigeria rural society. Owerri: African Scholars' Publishing Company.

- ODU-LEEDS (2013-2016). Odukpani Local Economic Empowerment and Development Strategy 2, 2013-2016 (ODU-LEEDS).

- $\quad$ Ojong, M.U, Iji, M.E., Angioha, P.U. (2019). Curing Socio-Economic ILLS in Obudu Local Government Area: An Assessment of Non-Governmental Agencies Activities. Journal of Social Service and Welfare.1(2): 38-45.

- Toyobo A. E. \& Adetunji, M. A. (2014). Travel behaviour of rural people in developing countries. Civil and Environmental Research. 3, 8. 